\title{
Pengolahan Deterjen Menggunakan Teknologi Elektrokoagulasi dengan Elektroda Aluminium
}

\author{
Hudori $^{1}$ \& P. Soewondo ${ }^{2}$ \\ ${ }^{1}$ Jurusan Teknik Lingkungan UII, Jl. Kaliurang km 14.4 Yogyakarta, 55584 \\ ${ }^{2}$ Departemen Teknik Lingkungan ITB, Jl. Ganesha 10 Bandung, 40132 \\ email1 : hudori@ftsp.uii.ac.id \\ email²: prayatnisoe@yahoo.com
}

\begin{abstract}
Abstrak
Elektrokoagulasi adalah teknologi pengolahan air dengan menggunakan proses elektrokimia dimana anoda akan melepaskan koagulan aktif berupa ion Al atau Fe ke dalam larutan. Tujuan penelitian ini adalah mengetahui laju penurunan konsentrasi deterjen, COD dari air limbah yang diolah pada reaktor elektrokoagulasi dan mengetahui parameter desain elektrokoagulasi yang sesuai untuk pengolahan air bekas cucian dalam skala rumah tangga. Reaktor elektrokoagulasi dioperasikan secara batch dengan menggunakan limbah dari jasa laundry. Elektroda yang digunakan adalah aluminium dengan kemurnian 99.7\%. Variasi kerapatan arus yang digunakan adalah 50, 75 dan 100 A/m2. Parameter yang diukur adalah surfaktan, COD, kekeruhan, konduktivitas, pH dan suhu. Hasil percobaan menunjukkan bahwa untuk konfigurasi monopolar dan bipolar dengan waktu detensi 30 menit tingkat penyisihan surfaktan mencapai 70\%, sedangkan COD mencapai 80\%. Berdasarkan tingkat penyisihan, reaktor elektrokoagulasi dengan konfigurasi monopolar dan bipolar tidak menunjukkan perbedaan yang signifikan pada pengolahan air limbah laundry.
\end{abstract}

Kata kunci: Elektrokoagulasi, deterjen, elektroda

\section{Pendahuluan}

Kebutuhan air bersih selalu mengalami peningkatan, namun hal ini tidak disertai dengan peningkatan kualitas dan kuantitas air bersih. Berbagai cara dilakukan untuk melakukan pengolahan air baik secara fisik, kimia maupun biologis. Salah satu teknologi yang dapat menghasilkan kualitas hasil pengolahan yang baik adalah elektrokoagulasi. Elektrokoagulasi adalah teknologi pengolahan air dengan menggunakan proses elektrokimia dimana anoda akan melepaskan koagulan aktif berupa ion $\mathrm{Al}$ atau $\mathrm{Fe}$ ke dalam larutan.

Pada penelitian ini, teknologi elektrokoagulasi digunakan untuk mengolah deterjen yang dihasilkan dari kegiatan mencuci pakaian. Hal ini dilakukan karena salah satu aktifitas yang menggunakan air bersih dalam jumlah cukup besar adalah mencuci pakaian, yaitu sekitar 22\% dari total pemakaian (Woodwell et.al 1995). Apabila air bekas cucian ini dapat diolah maka hasil pengolahannya dapat dimanfaatkan kembali untuk kegiatan yang sama.

Untuk melakukan pengolahan air dalam skala rumah tangga maka dibutuhkan desain dari elektrokoagulasi yang sesuai. Beberapa parameter harus dipertimbangkan supaya teknologi ini 
dapat diaplikasikan dan mudah dioperasikan. Dalam penelitian ini pertimbangan tersebut akan diteliti dan dilakukan pembahasan terhadapnya.

\section{Metode Penelitian}

\section{a. Reaktor Elektrokoagulasi}

Untuk pengoperasian secara batch, reaktor elektrokoagulasi yang digunakan berkapasitas $0.5 \mathrm{~L}$ yang dilengkapi dengan peralatan stirrer untuk mengaduk air limbah supaya konsentrasi koagulan menjadi homogen.

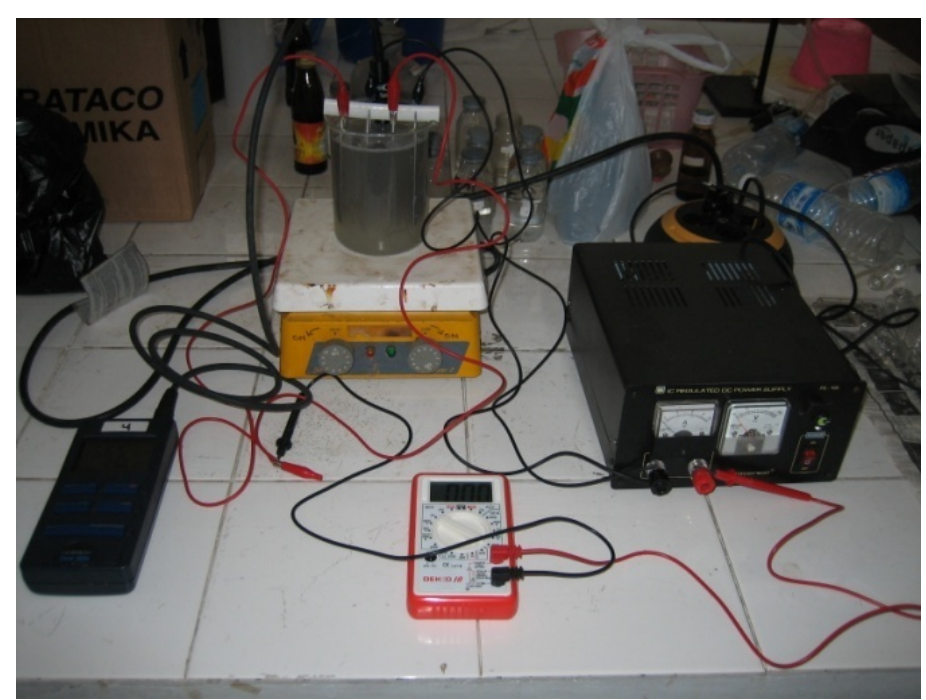

Gambar 1. Rangkaian Peralatan Elektrokoagulasi

Elektroda yang digunakan adalah plat Aluminium (99.7\%) dengan ukuran 5x10 cm sebanyak 4 buah. Luas permukaan elektroda anoda pada percobaan ini sebesar $0.01 \mathrm{~m}^{2}$ sehingga diperoleh rasio luas permukaan elektroda terhadap volume reaktor (SA/V) sebesar $20 \mathrm{~m}^{2} / \mathrm{m}^{3}$.

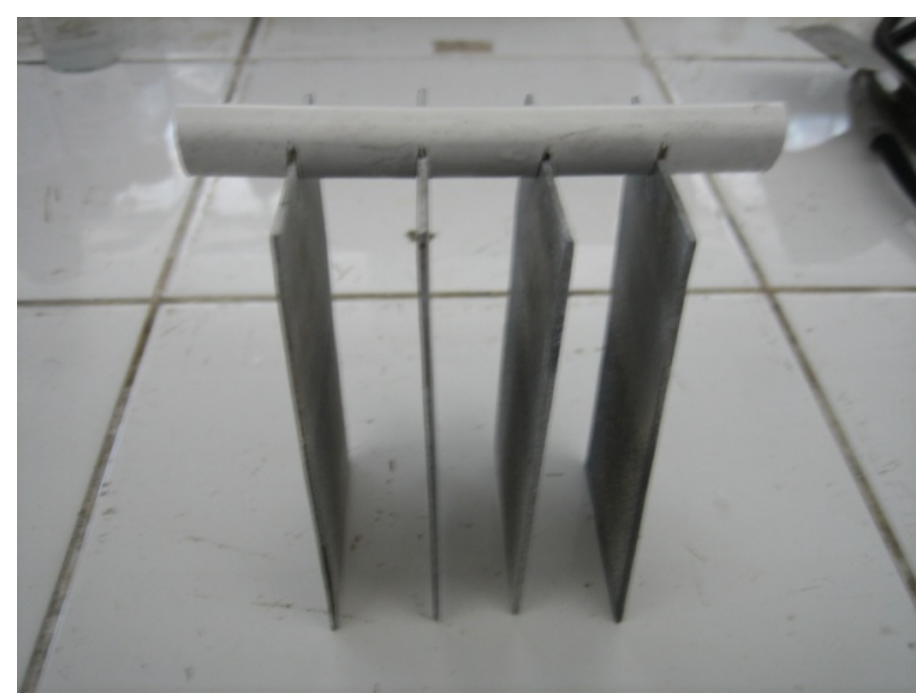

Gambar 2. Plat Aluminium Yang Digunakan 


\section{b. Proses Elektrokoagulasi}

Percobaan elektrokoagulasi dilakukan selama 60 menit untuk setiap running dengan interval 10 menit untuk pengambilan sampelnya. Semua percobaan dilakukan pada suhu ruangan, yaitu sekitar $25^{\circ} \mathrm{C}$. Setiap sampel yang diambil langsung diukur nilai kekeruhan, $\mathrm{pH}$ dan suhu. Selanjutnya sampel tersebut dianalisa kandungan surfaktan dengan metode MBAS dan kandungan bahan organik dengan tes COD. Untuk sampel yang tidak dapat langsung dianalisa maka dilakukan pengawetan sesuai metode yang ada. Pada penelitian ini $\mathrm{pH}$ air limbah laundry berkisar antara 8-10.

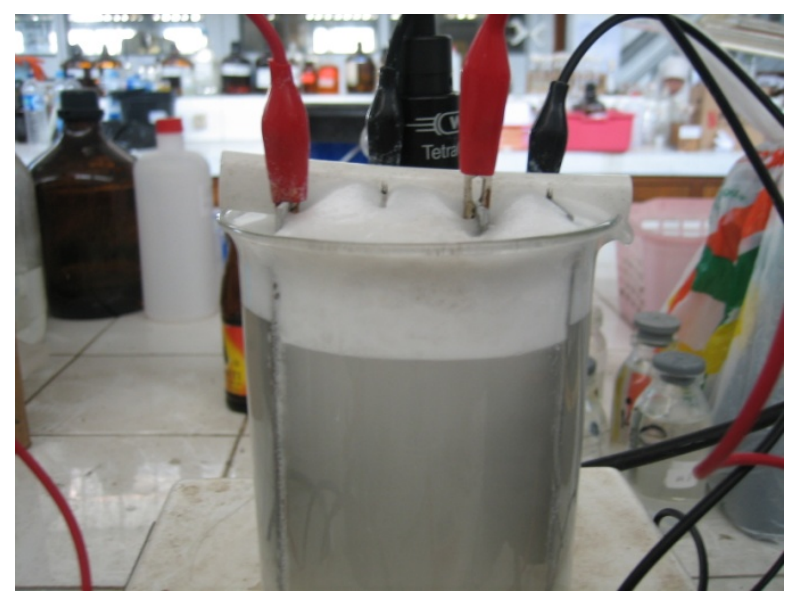

Gambar 3. Proses Elektrokoagulasi

Dari hasil percobaan tersebut akan diperoleh data yang berisi perubahan konsentrasi dari parameter penelitian. Laju perubahan konsentrasi pada reaktor elektrokoagulasi yang dilakukan pada penelitian ini dinyatakan dengan model kinetika reaksi orde satu (Emamjomeh, 2006) yaitu :

$$
C_{t}-C_{o} e^{-k t}
$$

Dengan $\mathrm{C}_{\mathrm{t}}$ adalah konsentrasi pada waktu $\mathrm{t}, \mathrm{C}_{\mathrm{o}}$ adalah konsentrasi di awal percobaan $(\mathrm{t}=0)$ dan $k$ adalah nilai kinetika perubahan konsentrasi. Untuk mendapatkan nilai k perlu diplotkan nilai -ln $\left(\mathrm{C}_{\mathrm{t}} / \mathrm{C}_{\mathrm{o}}\right)$ terhadap waktu detensi. Dimana nilai $\mathrm{k}$ merupakan gradien dari persamaan garis kurva tersebut. Dengan membandingkan nilai $k$ dari perlakuan penelitian maka akan diperoleh variasi penelitian yang menghasilkan efisiensi yang paling baik.

\section{Hasil dan Pembahasan}

\subsection{Karakteristik Air Limbah Laundry}

Air limbah yang digunakan pada penelitian ini berupa limbah cair asli yang berasal dari jasa laundry yang ada di daerah perumahan Griya Taman Asri, Donoharjo, Sleman. Hasil analisa yang dilakukan diperoleh karakteristik dari air limbahnya adalah sebagaimana Tabel 1. 
Tabel 1. Karakteristik air limbah

\begin{tabular}{|l|l|c|c|c|}
\hline No & \multicolumn{1}{|c|}{ Parameter } & Konsentrasi & Baku Mutu & Satuan \\
\hline 1. & Surfaktan (MBAS) & $256.87-363.72$ & $5^{*}$ & $\mathrm{mg} / \mathrm{L}$ \\
\hline 2. & COD & $599.44-754.35$ & $100^{*}$ & $\mathrm{mg} / \mathrm{L}$ \\
\hline 3. & Kekeruhan & $144-759$ & & $\mathrm{NTU}$ \\
\hline 4. & $\mathrm{pH}$ & $8.67-10.53$ & $6-9 *$ & \\
\hline 5. & Suhu & $23.6-26.0$ & & ${ }^{0} \mathrm{C}$ \\
\hline
\end{tabular}

*KEP-51/MENLH/10/1995

** PP No 82 Tahun 2001

Hasil pemeriksaan tersebut menunjukkan bahwa konsentrasi kandungan polutan dalam air limbah laundry telah melebihi baku mutu yang ditetapkan. Parameter yang konsentrasinya sangat tinggi adalah surfaktan dan COD. Dengan tingginya kandungan surfaktan dan COD akan menimbulkan dampak yang negatif bagi biota jika air limbah tersebut dibuang ke lingkungan perairan.

\subsection{Proses Elektrokoagulasi Pada Percobaan Batch}

Pada penelitian ini digunakan kuat arus yang berasal dari DC Power Supply dengan kapasitas 0 - 10 A dan tegangan 0 - 50 Volt. Kuat arus yang dialirkan ke elektroda aluminium sebesar $0.25-1 \mathrm{~A}$ untuk memperoleh kerapatan arus yang diinginkan yaitu 50, 75 dan 100 A/m2. Untuk percobaan secara batch, reaktor yang digunakan berupa beker glass dengan kapasitas $600 \mathrm{~mL}$. Untuk mendapatkan kondisi yang homogen, magnetic stirrer diatur pada skala 5 untuk semua percobaan pada penelitian ini. Selama proses elektrokoagulasi selama 60 menit, dilakukan pengambilan sampel pada interval waktu 10 menit. Pengukuran secara langsung dilakukan untuk parameter kekeruhan, pH dan suhu. Sampel yang diambil dimasukkan dalam botol sampel yang kemudian dianalisa kandungan surfaktan dan COD. Hasil pengukuran untuk proses batch yang sudah dilakukan sesuai variasi penelitian adalah sebagai berikut:

\section{a. Penyisihan Surfaktan}

Pemeriksaan surfaktan pada penelitian ini mempergunakan metode MBAS, yaitu metode pemeriksaan surfaktan berjenis anionik. Pada penelitian ini, kandungan LAS dari deterjen yang digunakan oleh jasa laundry sebesar 25 \%. Pada percobaan elektrokoagulasi dengan konfigurasi monopolar dan bipolar diperoleh data dari sampel yang diambil pada interval waktu 10 menit yang dapat dilihat pada gambar 4. 

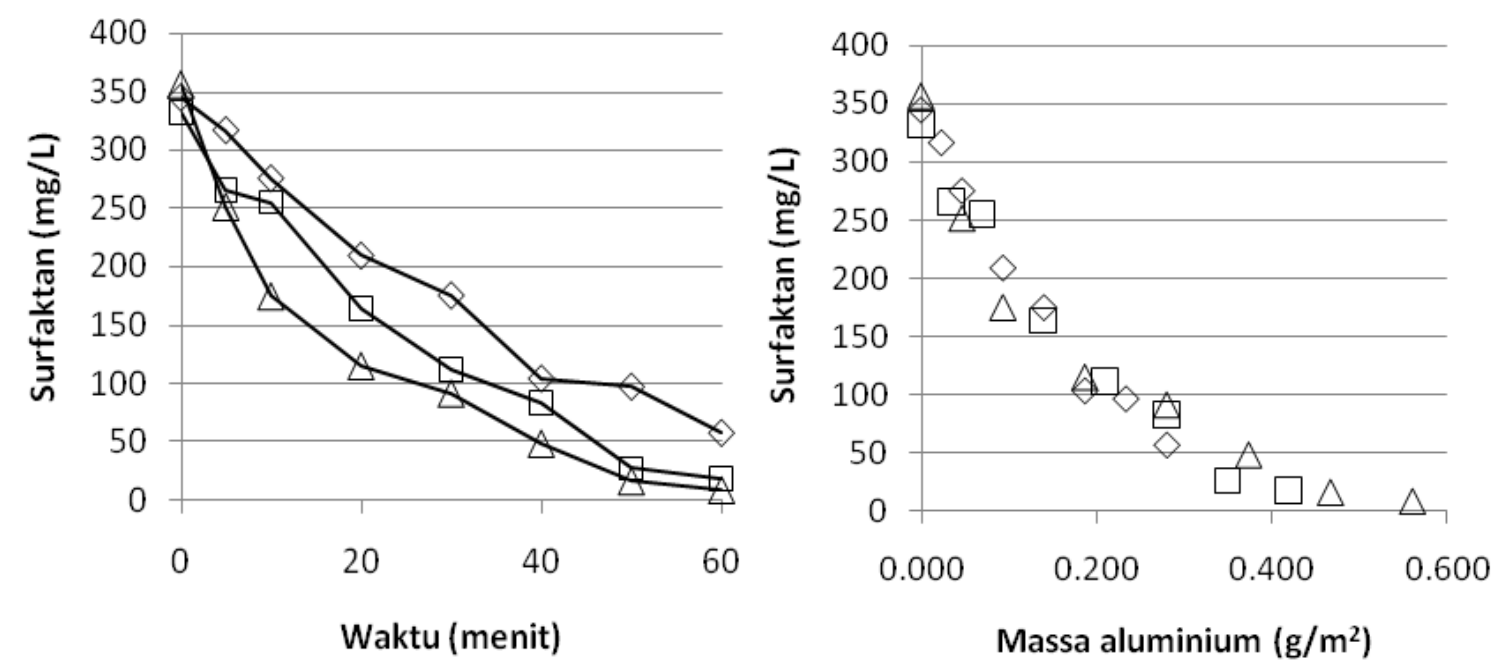

$\smile 50 \mathrm{~A} / \mathrm{m} 2 \square 75 \mathrm{~A} / \mathrm{m} 2 \triangle 100 \mathrm{~A} / \mathrm{m} 2$ $\diamond 50 \mathrm{~A} / \mathrm{m} 2 \quad \square 75 \mathrm{~A} / \mathrm{m} 2 \quad \triangle 100 \mathrm{~A} / \mathrm{m} 2$

Gambar 4. Profil penurunan konsentrasi surfaktan pada konfigurasi monopolar dengan variasi kerapatan arus

Pada kurva gambar 4 terlihat bahwa penurunan konsentrasi surfaktan yang tajam terjadi pada kerapatan arus $100 \mathrm{~A} / \mathrm{m}^{2}$ terutama pada menit awal. Sedangkan untuk kerapatan arus 50 dan 75 A/m2 cenderung landai. Sedangkan massa aluminium yang dibutuhkan untuk mendapatkan konsentrasi surfaktan yang paling rendah yaitu 9,04 mg/L diperoleh pada 0,560 g/m².
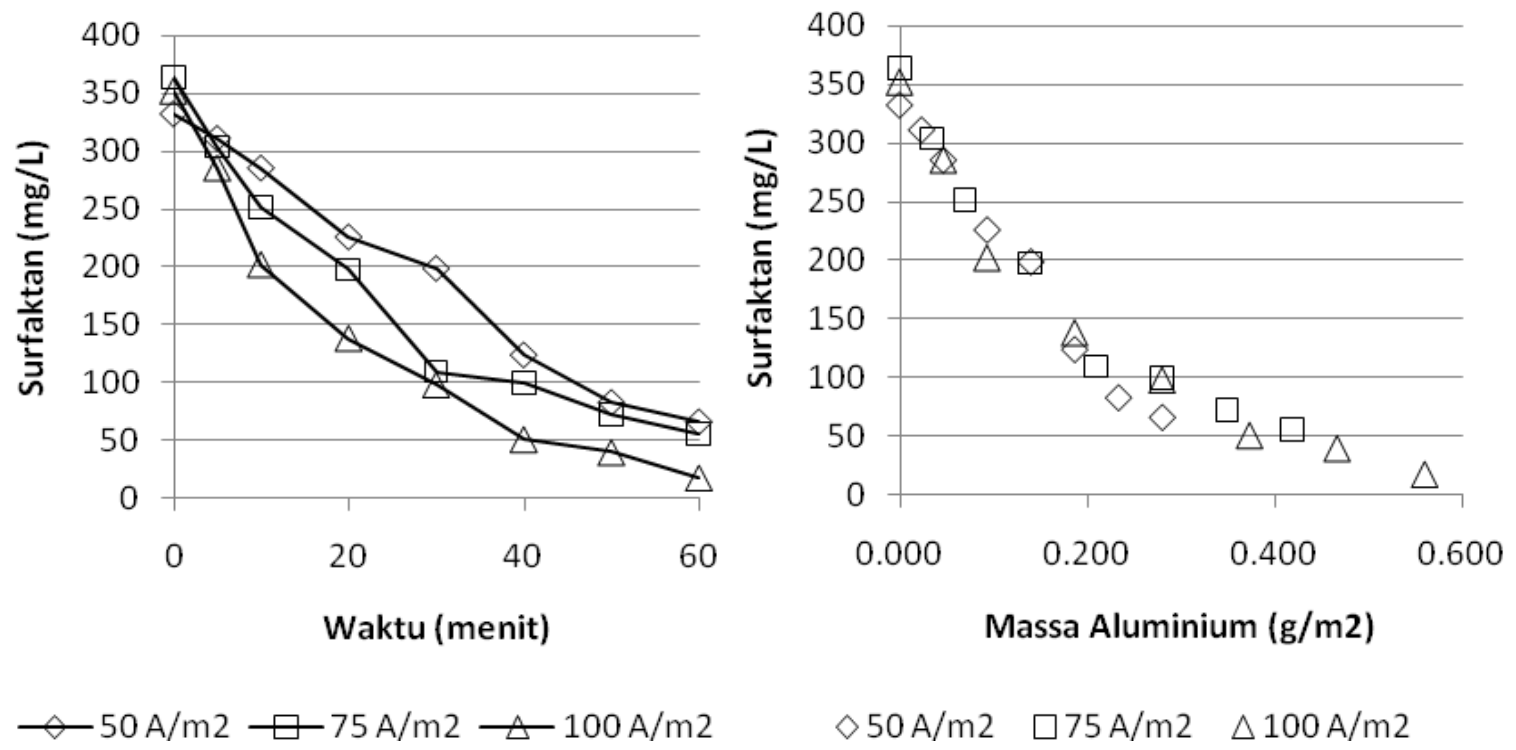

$\diamond 50 \mathrm{~A} / \mathrm{m} 2 \quad \square 75 \mathrm{~A} / \mathrm{m} 2 \quad \triangle 100 \mathrm{~A} / \mathrm{m} 2$

Gambar 5. Profil penurunan konsentrasi surfaktan pada konfigurasi bipolar dengan variasi kerapatan arus

Penurunan konsentrasi surfaktan yang terjadi pada konfigurasi bipolar menunjukkan pola yang sama dengan konfigurasi monopolar. Dimana kerapatan arus $100 \mathrm{~A} / \mathrm{m}^{2}$ yang memiliki penurunan paling tinggi. Untuk konfigurasi bipolar konsentrasi surfaktan yang paling rendah yaitu 16,79 mg/L diperoleh pada massa aluminium sebesar $0,560 \mathrm{~g} / \mathrm{m}^{2}$. 
Dari kedua konfigurasi diperoleh bahwa kerapatan arus $100 \mathrm{~A} / \mathrm{m} 2$ memberikan hasil yang paling baik. Hal ini disebabkan jumlah ion aluminium yang terbentuk berbanding lurus dengan kuat arus yang mengalir sesuai dengan hukum Faraday. Dan kerapatan arus $100 \mathrm{~A} / \mathrm{m} 2$ menggunakan kuat arus yang lebih tinggi dibandingkan kerapatan arus yang lain. Sehingga proses koagulasi yang terjadi menghasilkan efisiensi yang paling baik.

Terjadinya penyisihan surfaktan pada percobaan ini disebabkan beberapa proses. Menurut Ge (2004) penyisihan surfaktan dalam proses elektrokoagulasi disebabkan karena terjadi adsorbsi surfaktan pada permukaan partikel sehingga terbentuk permukaan yang hydropobic yang menyebabkan partikel dalam air limbah akan naik ke permukaan dengan bantuan gelembung gas yang terbentuk. Sedangkan menurut Aboulhassan (2006) penurunan kandungan surfaktan pada penelitian ini disebabkan terjadinya suatu proses yang disebut Adsortive Micelle Flocculation (AMF).

\section{b. Penyisihan COD}

Pemeriksaan COD diperlukan untuk mengetahui kandungan bahan organik yang terdapat di dalam air limbah laundry. Nilai COD yang diperiksa pada penelitian ini adalah konsentrasi COD total, sehingga sampel yang akan diperiksa tidak di saring terlebih dahulu. Hasil pemeriksaan COD untuk konfigurasi monopolar dan bipolar dapat dilihat pada gambar 6.
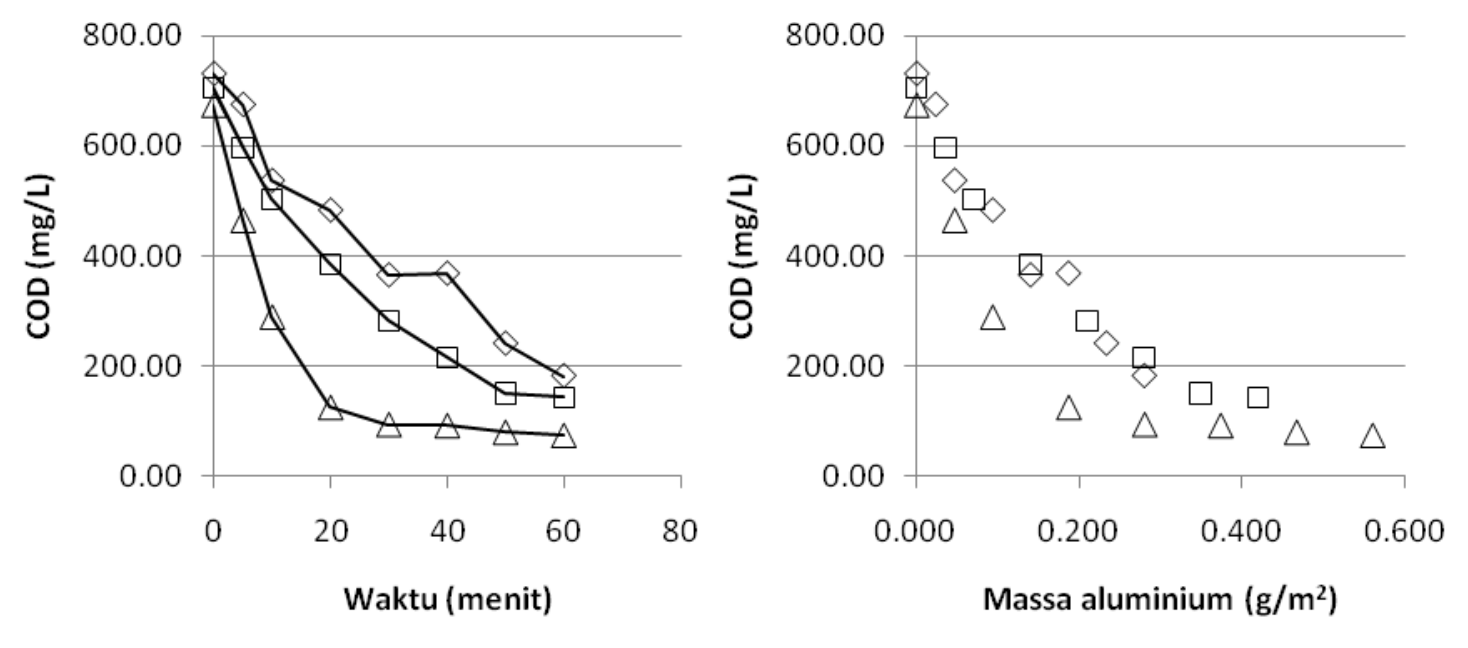

\section{$\smile 50 \mathrm{~A} / \mathrm{m} 2 \multimap 75 \mathrm{~A} / \mathrm{m} 2 \triangle 100 \mathrm{~A} / \mathrm{m} 2$}

$\diamond 50 \mathrm{~A} / \mathrm{m} 2 \quad \square 75 \mathrm{~A} / \mathrm{m} 2 \quad \triangle 100 \mathrm{~A} / \mathrm{m} 2$

Gambar 6. Profil penurunan COD pada konfigurasi monopolar dengan variasi kerapatan arus

Dari Gambar 6 terlihat bahwa untuk kerapatan arus $100 \mathrm{~A} / \mathrm{m}^{2}$ terjadi penurunan yang sangat tajam pada menit ke-0 sampai menit ke-20. Kemudian dilanjutkan dengan penurunan yang lebih landai pada menit berikutnya. Sedangkan untuk kerapatan arus $75 \mathrm{~A} / \mathrm{m}^{2}$ tingkat penurunannya cenderung konstan. Hal ini berbeda dengan kerapatan arus $50 \mathrm{~A} / \mathrm{m}^{2}$ yang memiliki tingkat penurunan yang 
tidak konstan. Konsentrasi surfaktan yang paling rendah yaitu 76.09 mg/L diperoleh pada massa aluminium sebesar $0.560 \mathrm{~g} / \mathrm{m}^{2}$.

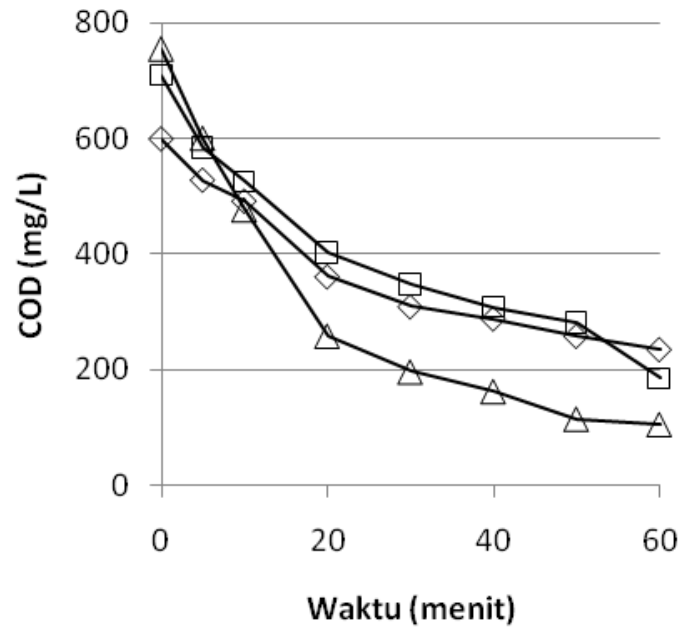

$\neg 50 \mathrm{~A} / \mathrm{m} 2 \square 75 \mathrm{~A} / \mathrm{m} 2 \triangle 100 \mathrm{~A} / \mathrm{m} 2$

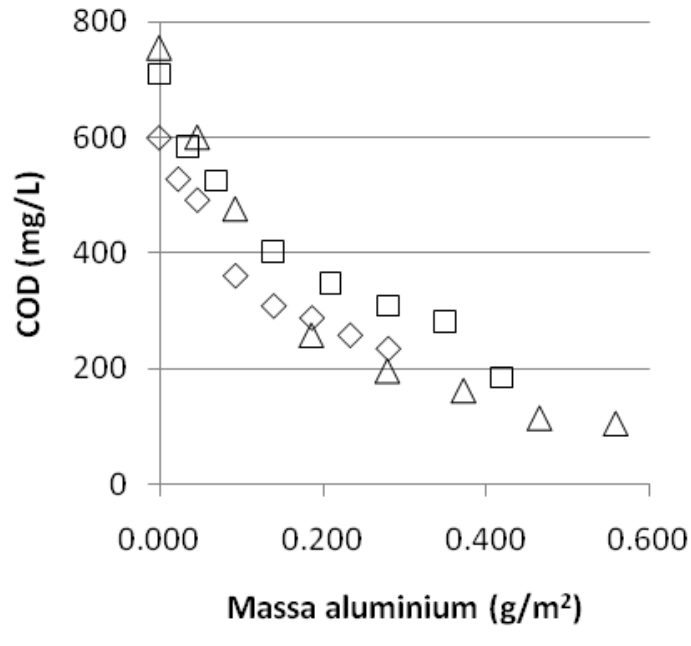

$\diamond 50 \mathrm{~A} / \mathrm{m} 2 \quad \square 75 \mathrm{~A} / \mathrm{m} 2 \quad \triangle 100 \mathrm{~A} / \mathrm{m} 2$

Gambar 7. Profil penurunan COD pada konfigurasi bipolar dengan variasi kerapatan arus

Pada konfigurasi bipolar, tingkat penurunan untuk kerapatan arus 100 A/m2 cenderung tajam sampai menit ke-20. Sedangkan untuk kerapatan arus 50 dan $75 \mathrm{~A} / \mathrm{m} 2$ memiliki pola yang hampir sama yaitu cenderung landai.

Dari kedua konfigurasi diperoleh bahwa kerapatan arus $100 \mathrm{~A} / \mathrm{m} 2$ memberikan hasil yang paling baik. Hal ini disebabkan jumlah ion aluminium yang terbentuk berbanding lurus dengan kuat arus yang mengalir sesuai dengan hukum Faraday. Dan kerapatan arus 100 A/m2 menggunakan kuat arus yang lebih tinggi dibandingkan kerapatan arus yang lain. Massa aluminium yang dihasilkan sebesar $0.560 \mathrm{~g} / \mathrm{m}^{2}$ mampu menurunkan konsentrasi COD sampai $104.2 \mathrm{mg} / \mathrm{L}$.

Penyisihan COD yang terjadi pada proses elektrokoagulasi disebabkan oleh oksidasi langsung di anoda yang dilanjutkan dengan koagulasi dan elektroflotasi, (Ge, 2004). Menurut Mollah (2004) mekanisme penyisihan yang umum terjadi di dalam elektrokoagulasi terbagi dalam tiga faktor utama, yaitu : (a) terbentuknya koagulan akibat proses oksidasi elektrolisis pada elektroda, (b) destabilisasi kontaminan, partikel tersuspensi dan pemecahan emulsi, dan (c) agregatisasi dari hasil destabilisasi untuk membentuk flok.

Sedangkan menurut Aboulhassan (2006) penurunan COD juga disebabkan proses yang sama dengan surfaktan yaitu terjadi proses Adsortive Micelle Flocculation. Selain itu sebagian besar bahan organik yang terbaca sebagai COD merupakan senyawa surfaktan. Sehingga bila konsentrasi surfaktan mengalami penurunan, maka nilai COD juga menurun. 


\section{Kesimpulan}

Dari hasil penelitian yang telah dilakukan maka dapat diambil kesimpulan sebagai berikut:

- Hasil penelitian menunjukkan bahwa untuk waktu detensi 30 menit tingkat penyisihan surfaktan sebesar 74.25\% untuk monopolar dan 72.31\% untuk bipolar.

- Tingkat penyisihan COD untuk waktu detensi 30 menit sebesar 85.80\% untuk monopolar dan 79.11\% untuk bipolar.

- Berdasarkan tingkat penyisihan, reaktor elektrokoagulasi dengan konfigurasi monopolar dan bipolar tidak menunjukkan perbedaan yang signifikan pada pengolahan air limbah laundry

\section{Daftar Pustaka}

Aboulhassan, M. A., Souabi, S., Yaacoubi, A., dan Baudu, M. (2006). Removal of surfactant from industrial wastewaters by coagulation flocculation process, Int. J. Environ. Sci. Tech., 3 (4), 327-332.

Emamjomeh, M. M., dan Sivakumar, M. (2006). An empirical model for defluoridation by batch monopolar electrocoagulation/flotation (ECF) process, Journal of Hazardous Materials, B131, 118-125.

Ge, J., Qu, J., Lei, P., dan Liu, H. (2004). New bipolar electrocoagulation-electroflotation process for the treatment of laundry wastewater, Separation and Purification Technology, 36, 33-39.

Hoinkis, J., dan Panten, V. (2008). Wastewater recycling in laundries-From pilot to large-scale plant, Chemical Engineering and Processing.

Holt, P. K., Barton, G. W., and Mitchell, C. A. (1999). Electrocoagulation as A Wastewater Treatment, The Third Annual Australian Environmental Engineering Research Event. 23-26 November Castlemaine, Victoria.

Holt, P. K., Barton, G. W. and Mitchell, C. A. (2001). The role of current in determining pollutant removal in a batch electrocoagulation reactor. In 6th World Congress of Chemical Engineering, Conference Media CD, Melbourne, Australia.

Holt, P. K., Barton, G. W., and Mitchell, C. A. (2004). Deciphering the Science Behind Electrocoagulation to Remove Suspended Clay Particles from Water, Water Science and Technology, Vol. 50 No. 12 pp 177-184, IWA Publishing.

Holt, P. K., Barton, G. W., and Mitchell, C. A. (2004). Future for Electrocoagulation as A Localised Water Treatment Technology, Chemosphere, Elsevier Ltd.

Letterman, R. D., Amirtharajah, A. dan O'Melia, C. R. (1999). Coagulation and Flocculation dalam Water Quality and Treatment, A Handbook of community watersupplies, editor: Letterman, R. D. dan American Water Works Association, McGraw-Hill, New York

Mills, D. (2000). A New Process for Electrocoagulation, Journal American Water Works Association, 92(6) pp 34-43. 
Morel A., Diener S. (2006). Greywater Management in Low and Middle-Income Countries, Review of different treatment systems for households or neighbourhoods. Swiss Federal Institute of Aquatic Science and Technology (Eawag). Dübendorf, Switzerland.

Mollah, M. Y. A., Morkovsky, P., Gomes, J. A. G., Kesmez, M., Parga, J., and Cocke, D. L. (2004). Fundamentals, Present and Future Perspectives of Electrocoagulation, Journal of Hazardous Materials, B114: 199-210.

Mollah, M. Y. A., Schennach, R., Parga, J. R., and Cocke, D. L. (2001). Electrocoagulation (EC) Science and Applications, Journal of Hazardous Materials. B84: 29-41.

Shin, S. H., Kim, Y. H., Jung, S. K., Suh, K. H., Kang, S. G., Jeong, S. K., and Kim, H. G. (2004). Combined Performance of Electrocoagulation and Magnetic Separation Processes for Treatment of Dye Wastewater, Korean J. Chem. Eng. pp 806-810, Korea.

Song, J., Han, M., Chung, T., and Choi, S. (2000). The Effect of Coagulation Time on the Turbidity Removal Efficiency in Electrocoagulation, School of Civil, Urban and Geosystem Engineering, Seoul National University, Seoul, Korea.

Talens-Alesson, F. I., Anthony, S., dan Bryce, M. (2004). Complexation of organic compounds in the presence of $\mathrm{Al}^{3+}$ during micellar flocculation, Water Research, 38, 1477-1483.

Woodwell, J.C., Dyer, J., Pinkham, R., and Chaplin, S. (1995). Water Effiency for Your Home, Rocky Mountain Institute, Third Edition. 